\title{
Job-induced Commuting between Two Residences - Characteristics of a Multilocational Living Arrangement in the Late Modernity
}

\author{
Darja Reuschke
}

\begin{abstract}
Against the background of the ongoing flexibilisation of labour markets and a rising labour force participation of (highly) qualified women, job-related commuting between a main and secondary residence has become more important in Western capitalist countries as is the case in contemporary Germany. The limited number of recent empirical studies on this kind of multilocational living arrangement almost entirely focuses on commuters in couple/family households. The main objective of this article is, firstly, to provide data about the characteristics and formation contexts of job-related multilocational household organisations as a whole, in order to make a contribution to the discussion of the forms and causes of this currently important phenomenon. Secondly, by means of comparison analyses, the multilocational form of living is compared to the group of long-distance movers, in order to provide insights into who prefers commuting to migration with the complete household under which circumstances. The article draws on data of a field research study, which have been obtained from an individual based random sample from official registers of inhabitants of four metropolises in Germany. The sample was restricted to individuals with specific characteristics (in-movers, age 25 to 59). The fully structured postal interviews were complemented by qualitative telephone interviews with selected commuters. The results show that commuters are a heterogeneous group. Living in a partnership and the social connections established thereby play a prominent role for multilocational household organisations. Among male commuters, one can distinguish between those who are young, never married and predominantly childless, on the one hand, and a group of older married commuters with children in the household, on the other. The vast majority of female commuters, however, live childless. As men commute between two residences even if they live with a family, they significantly more often have a job-related secondary residence than women. Late modern characteristics of job-related multilocational living arrangements are dual earner households for male commuters and high occupational positions for female commuters. The commuting between two accommodations is strongly connected to the career entry, on the one hand, and is also important in a later occupational career phase as a partly longer-lasting pe-
\end{abstract}


riod, on the other hand. It may be suggested that the rise of fix-term employment will further increase the importance of multilocational living arrangements in Late Modernity.

Keywords: secondary residence $\cdot$ commuters $\cdot$ circular migration $\cdot$ job-related geographical mobility $\cdot$ long-distance migration $\cdot$ multivariate comparison group analyses

\section{Introduction}

In recent years, advanced capitalist countries have witnessed dramatic social and economic changes that have been brought about by the transformation from an industrial society to a service/knowledge society. Among the key labour market trends are the decline of full-time uninterrupted working careers, the flexibilisation of working times and labour contracts, and the reorganisation of work by means of projectoriented work. Besides such changes in the working world, which contributed to an overall increase of job insecurity, radical demographic and social changes occurred, including declining fertility rates, growing numbers of one- and two-person-households, and (in the case of West-Germany and other Western capitalist countries) a decreasing importance of the male breadwinner/female homemaker family model which is accompanied by a rising female labour force. As a consequence, working and social lives have changed profoundly in societies in Western countries. Current literature refers to this phenomenon as Late Modernity.

Under the conditions of progressing societal modernisation and labour market flexibilisation, some individualisation theorists have been postulating a rapid increase of spatial mobility and the development towards a 'mobile single society' with 'hypermobile multinationals playing workers' (Sennett 2000, Beck 1986, 1999, Peck 1996, Bonß et al. 2004). However, due to the continuous rise of the employment rate among women in the Western part of Germany and other Western capitalist countries, the proportion of dual earner households has been growing (Blossfeld/ Drobnič 2001). This stands in opposition to an increasing migration rate of couple and family households (Van Ommeren et al. 1998, Wagner 1989, Kalter 1998, Jürges 2006). Considering these findings of migration research, it comes as no surprise that the scope of annual interregional migration in Germany - measured by the changes of residence between the federal states - has been on a low, even slightly decreasing level over the last years: In 2000, the rate of moves between the federal states was 1.5 per cent of the total population and slightly dropped to 1.3 per cent in 2007 (Statistisches Bundesamt 2002, 2009).

As recent studies on job-related geographical mobility show, this ambivalence between mobility theories in Late Modernity, on the one hand, and empirical evidence on interregional migration, on the other, is due to the variety of contemporary job-related geographical mobility that cannot be captured sufficiently by official 
statistics on interregional migration (Schneider et al. 2002, Schneider/Meil 2008, Reuschke 2010). Hence, the commuting statistics of the German Microcensus documents a clear increase in job-induced commuting between two residences: In the Federal Republic 357,000 persons with a job-related secondary residence (including trainees) were registered in 2004. This corresponds to an increase of 12 per cent compared to 1996 (Statistisches Bundesamt 2005: 61). Upon this circular form of job-related mobility much public attention has been paid during the last years (see, for example, Clorius 2006 and Fröhlich/Detering 2010 in the German weekly journal Die Zeit). Circular migration is also widely discussed in research on developing countries in which context conditions and mobility patterns of multilocational household structures are different from those in advanced capitalist countries. This article focuses only on job-related multilocational household organisations in Western capitalist countries, i.e. late modern societies, drawing on Germany as an example.

The limited number of empirical studies on job-induced commuting between two residences that have been conducted so far, focuses almost exclusively on commuters in a couple or family household ('commuting partnerships'). This relates to the assumption that multilocational household organisations are an alternative geographical arrangement to migration (with all household members) for couple/ family households due to their complex mobility decisions in Late Modernity (Van der Klis 2008, Van der Klis/Mulder 2008, Green et al. 1999). Moreover, recent studies predominantly apply qualitative research designs and thus are based on (small) non-random samples, so that conclusions can be drawn only for single cases and specific couples respectively (e.g. academic couples, dual career couples). Taken together, only little is known about who has job-related secondary residences in general and whether and to what extent this form of circular mobility is relevant for workers in living arrangements other than couple/family households.

Previous empirical research that compare commuting partnerships with interregional migrants and/or non-migrants provide insights into contemporary migration decisions of specific household types (Schneider/Meil 2008, Schneider et al. 2002). However, further research that provides more general empirical evidence on who decides for commuting, migration or spatial immobility and why is necessary in order to improve our knowledge of contemporary job-related geographical mobility patterns and to understand the migration behaviour of persons in different living arrangements and household compositions. With the focus on the determining factors for and contextual conditions of job-induced multilocational household organisations, this article tries to make a contribution to fill this research gap by comparing commuters with a job-used secondary residence with interregional migrants. The main research questions addressed are: Which socio-structural features are characteristic of persons with a job-related secondary residence? What distinguishes persons with a job-related secondary residence from persons with a long-distance move with the whole household? Which personal motives and formation contexts are relevant for the circular form of migration? Is it a short-term or long-term arrangement? 
The following section further elaborates on previous research and migration theory. On this basis research-guiding hypotheses will be formulated. After the description of the sample design and preliminary methodological remarks (section 3) empirical results will be presented in section 4. Finally, the results will be summarised and perspectives for future research highlighted.

\section{Previous research, theory and hypotheses}

Although the appearance of commuters with job-used secondary residences has attracted attention in social sciences particularly in the last couple of years, this multilocational way of living is not a new phenomenon of late modern societies (see Limmer/Schneider 2008: 13-15). In the field of geography, weekly commuting of untrained workers in the construction industry has repeatedly been subject to regional-economic studies in rural, economically weak regions since the 1960s (Lutz/Kreuz 1968, Breyer 1970, Junker 1992, Hack/ 1992). These case studies make quite clear that the everyday life practices of commuters deviate from the collective patterns of life in industrial societies (Wood 2008), but are - due to low job qualifications and traditional gender relations (male breadwinner model) - still tightly linked to the First Modernity and the Fordistic era. The modern manifestation of weekly commuting from small villages and towns in economically weak regions to labour market centres like Munich or Vienna was shown to go in hand with a strong emotional place attachment and owner-occupied housing in case studies in Eastern Bavaria and Austria, conducted by Junker (1992), Hackl (1992) and Vielhaber (1987).

A more recent family-sociological research strand addresses job-induced multilocational household organisations within the context of social change and points to the formation of a "new choreography of working and family lives" due to changing gender roles, and the increase in the number of women in employment in general and in highly-qualified positions in particular (Green et al. 1999: 50). Here, the focus is on partnerships and families, whereas the emphasis of the studies has especially been on dual career couples in which both partners pursue highly-qualified occupations with their own professional career ambitions (Gross 1980, Gerstel/Gross 1984, Winfield 1985, Bunker et al. 1992, Anderson/Spruill 1993, Green 1995). Following Gross (1980), research on dual career couples distinguishes between two types of multilocational households: The "adjusting" type involves young and mostly childless couples. The commuting between different locations serves the initiation and advancement of the commuters' professional career. Older couples, on the other hand, who have lived together for many years and mostly have children who have left the family home constitute the "established type". At least one partner - usually the husband/male partner - is professionally established. Thus, decisions on spatial mobility often emanate from the wife/female partner, who wants to continue her professional career after child rearing. Consequently, the findings of previous studies on dual career commuting partnerships suggest that it is predominantly the occupational advancement of both partners - instead of structural strains that stem from unemployment, firm relocation and the like - that leads to multilocational liv- 
ing arrangements (Hardill 2002). However, these findings are most likely influenced by the research design that means only couples in which both partners work in high positions are investigated (cf. Van der Klis/Mulder 2008: 3). In contrast, some empirical studies in France and Germany that do not focus on dual career partnerships point to the relevance of structural strains for the formation of multilocational household organisations of couples and families (Bonnet et al. 2006, Schneider et al. 2002).

Judging from the dominance of recent research on dual career couples, almost all samples of persons with a job-related secondary residence comprise social groups with high professional positions. Samples of other empirical studies on multilocational household organisations which are not confined to dual career couples (Schneider et al. 2002, Green et al. 1999) are also characterised by a clear overrepresentation of highly-qualified employees among the commuters. This finding is in accordance with empirical evidence on interregional migration. Migration studies show that the educational level is a prominent determinant of migration and persons with a high professional training are characterised by a higher propensity to migrate (Wagner 1989, Jürges 1998b). Information on the partners' occupational positions, however, is not provided by investigations that are not confined to dual career couples.

In light of the priority given to questions related to partnership and family in almost all of the more recent studies on job-induced commuting between two residences (e.g. Weiske et al. 2009, Schneider/Limmer 2008, Van der Klis 2008, Van der Klis/Mulder 2008, Green et al. 1999; the study by Gräbe/Ott 2003 is an exception in this respect), one can make the assumption that partners in a shared household are a crucial characteristic of such multilocational ways of living. The always noticeable proportion of married persons and households with children points to a high relevance of married couples with children among commuters. This view is supported by the high proportion of subjects in the samples between their early 40s and their late 50s (Schneider et al. 2002, Green et al. 1999).

This currently dominating research interest on job-motivated multilocational living arrangements of shared households can be explained in terms of microeconomic migration theory. Accordingly, a household moves if the benefits from moving outweighs the sum of the costs. Several migration studies reveal that migration costs originate not only from monetary costs like moving expenses or higher rent/costs for owning a home in the destination area, but also include non-monetary costs that are provoked by the loss of, for example, familial/social relations, the owned home, and location-specific capital like the knowledge of the area (Sjaastad 1962: 84-85, DaVanzo 1981: 47). The cost-benefit-calculation appears to be clearly laid out for single households but becomes significantly more complex for households with two and more persons as all household members' benefits and costs need to be balanced (Mincer 1978). The findings from several migration studies show that it is the local attachment of children that significantly hinders family migration (e.g. Mulder/Hooimeijer 1999, Mulder 1993, Wagner 1989).

The unequal allocation of migration benefits and costs among household members bring about the tied partner phenomenon in couple/family households. That is 
the appearance of partners who do not move although they would have benefited from moving on an individual base (tied stayer). However, there are partners who move as the net benefit of moving is greater or equal to zero for the household as a whole although they experience individual losses from the move (tied mover). Most empirical research shows that mostly women are the tied partner (Bielby/ Bielby 1992, Büche/ 2000, Smits 2001, inter alia). Gender-role theory reveals that the gender-specific tied partner phenomenon cannot be explained only by means of economic measurement (higher income of male partners and the like) and points to the importance of gender-related asymmetric decision making structures in households (Bielby/Bielby 1992, Jürges 1998b). Some first empirical evidence for changes in typical gender-specific migration roles in late modern societies are provided by Smits, Mulder and Hooimeijer (2003) for the Netherlands. If both partners have larger individual gains compared to the gains resulting from staying together at the same location, the household will split up according to Mincer's microeconomic model of family migration.

Considering family migration and gender-role theory, one might suggest that the rise of multilocational household organisations in late modern societies relates to the decreasing willingness of women to be the tied partner. Multilocational household organisations could be an alternative option to migration and spatial immobility for couple/family households with an unbalanced cost-benefit-calculation on the level of the individual.

Despite societal modernisation, job-induced commuting between two residences is, however, a rather male phenomenon in late modern societies as it is manifested by the Microcensus in the case of Germany (Statistisches Bundesamt 2005) and suggested by investigations in Great Britain, France and South-Korea (Hogarth/ Daniel 1988, Green et al. 1999, Bonnet et al. 2006, Bertaux-Wiame 2006, Vignal 2006, Song-Chul 2001). With the focus being on multilocational household organisations of couple households and families, the French studies mentioned above link reasons for such developments to the "contrat social du couple" and "la limitation des engagements professionnels féminins dès lors qu'il y a d'enfants" ${ }^{\prime 1}$ (BertauxWiame/Tripier 2006).

Summing up, the review of migration theory and empirical work in the field of residential multilocality leads to the assumption that women and men with a jobrelated secondary residence nowadays commute less because of high migration costs that stem from home-ownership. On the contrary, living in dual earner and dual career households and thus the job-related place attachment of the partner are expected to be the major force for the commuting between two residences. In this regard, highly-qualified work is expected to be characteristic for commuters as are (highly) qualified positions for the (female) non-mobile partners.

1 "Social contract of the couple" and "the reduction of the labour market participation of women as soon as they have children" [D.R.]. 


\section{Sample design and methodological-analytical remarks}

In order to investigate characteristics of job-induced multilocational household organisations, a random sample of people with a secondary residence was drawn from official registers of inhabitants. Since in Germany registration is decentrally organised and registration data are normally kept track of by communal registry offices, it was necessary to select particular areas for investigation. However, it has to be noted that official registers do not provide information on reasons why persons register secondary residences. According to the German Microcensus 2004 the number of job-related secondary residences is highest in the federal states of Bavaria, Baden-Wuerttemberg and North Rhine-Westphalia (Statistisches Bundesamt 2005: 61), so that the economically strong state capitals Munich, Stuttgart und Dusseldorf were chosen as study areas. Berlin was chosen as another study area, since on the basis of available data on commuter flows with non-neighbouring states (Behnen/Ott 2006, Bogai et al. 2006) and the relocation of governmental and administrative institutions into the capital, a certain importance of job-related secondary residences could be assumed.

The population to be investigated considered all those who at the time of the drawing of the sample were aged 25 to 59 , and who had moved to the study areas during the last five years. Since only people who moved are integrated in the sample a comparison of commuters and spatially immobile persons cannot be conducted on the basis of this sample. With regard to the research design which is focused on comparison group analyses of different mobile living arrangements, and to ensure that enough addresses of in-movers with a secondary residence are drawn, two sub-samples with a priori defined samples sizes were selected: One of in-movers who had registered their secondary residence in the study areas and another of in-movers who had registered their main residence there (800 and 1,200 people respectively in Munich as well Dusseldorf). In Stuttgart, however, it was not possible to divide recent movers into main and secondary residences, so that a random sample of 4,000 people had to be compiled of those who either had a main or a secondary residence. Furthermore, only 68 people who had moved to Berlin had a secondary residence there at the time of the sampling; this is probably due to the municipal secondary residence tax which does not exist in the prosperous cities of Dusseldorf and Stuttgart and was first raised in Munich at the beginning of 2006. Altogether, about 10,500 persons were contacted, about 1,700 of them at their secondary residence.

The data were collected by means of a fully structured questionnaire that was sent out by mail. The field work period ran from January until March 2006. A total of 2,007 valid questionnaires were returned (response rate $=21.5$ per cent), one quarter of whom has a secondary residence $(n=483)$. Out of these about half as many ( $n$ $=226$ ) could be classified as commuters who commute between two accommodations for work ("commuters"). Extended semi-structured telephone interviews were conducted with 20 commuters in spring 2009, eleven of whom were still commuting between two residences at the time of the extended interview, three of whom had moved to another city either with the secondary or the main household. Altogether, 
seven respondents have multiple multilocational living experience, thus, changes concerning the perception and everyday practices in a multilocational way of living could be captured in these cases.

Half of the respondents with secondary residences out of the postal sample have two residences for reasons that do not relate to paid work. In short, the largest group is studying or takes part in vocational trainings in the study areas while keeping their parental home as main or secondary residence. Others moved to the respective metropolis for their career entry and keep their parental home due to family attachment. Finally, for a small group the multilocational household organisation exists only 'pro forma' in order to save motor vehicle tax or to keep a permanent address at the parental home after moving several times. All respondents that do not have a job-used secondary residence are not subject of the present research.

In addition to persons with secondary residences for job-related/job-unrelated reasons, the sample contains other mobile living arrangements: persons who moved to the study areas with their whole household over long distance (migration) or short distance (residential mobility), some of whom live with his/her partner in separated households, i.e. without a common residence, either in close proximity or at greater distance. In the literature the kind of partnership arrangement that involves commuting between two separate households is often labelled as living apart together (LAT). LAT-partnerships are another multilocational form of living that has attracted much attention in social sciences in the last couple of years (see, for example, Levin 2004, Schneider et al. 2002, Reuschke 2010). However, as will be presented in the following section, a clear distinction between commuters and LATs (including long distance LATs who commute between the separate residences over long distance) is not applicable to mobile living practices of individuals. Furthermore, the present sub-samples of commuters and long distance LATs are too small for comparison group analyses.

In order to investigate for whom commuting between two residences is an alternative to migration and for whom not, people were chosen for the comparison group who moved over a greater distance of at least $50 \mathrm{~km}$ into the study area and did not have a secondary residence. Furthermore, as respondents with a job-related secondary residence are defined as employed, only employed people are selected for the comparison group. The comparison group ("long distance movers") includes 837 respondents. A threshold of $50 \mathrm{~km}$ (or 60 minutes) is applied in the respective migration literature in order to distinguish residential mobility and long distance moves and thus more job-related moves respectively (Jürges 1998a, Wagner 1989, Schneider/Meil 2008). Accordingly, respondents in the present sample who moved from peri-urban areas to the respective metropolis with their whole household did so predominantly for personal/familial reasons, whereas two thirds of those interviewed employed long distance movers reported job-related reasons. Women are more often the tied mover (see section 2) and thus they reported significantly more frequently family related and personal reasons for their long distance move to the respective study area than men (although they might have changed their job subsequently to the move too). That is why the comparison group was not restricted 
to employed long distance movers who reported job-related reasons as principal motive for their move.

Due to the comparative research design, the presented empirical data on commuters with a job-used secondary residence are "relational" to some extent. However, I argue that only by means of comparison group analyses conclusions on specialities and formation contexts of the multilocational living arrangement can be drawn. Moreover, it has to be noted that the sample design might have consequences for the data interpretation as follows:

- Due to the sampling via the official register, only those persons could be addressed who had registered a residence in the researched areas. Persons working in these areas without an official secondary residence (e.g. during probation periods, short-term assignments) are not included in the sample.

- Only core cities of metropolitan regions were selected as the greatest numbers of job-used secondary residences and job-related in-moves could be assumed to dwell exactly here. Consequently, smaller cities and towns as well as peri-urban areas of the selected cities were not considered. Commuters in the excluded areas might differ from metropolitan commuters as far as socio-structural characteristics and commuting behaviour are concerned.

- Since only people who moved to the study area during the past five years were defined as population, commuters who have been living in job-used secondary residences in the respective study areas for six years and more are not included in the sample. These commuters might have specific characteristics that are not captured by the present study.

- The personal and household-related data refer to the respondents' present situation at the time of the standardised interview. This might differ from the personal/household situation at the time of moving to the respective city, which could date back a maximum of five years. The data do not capture changes of personal/familial circumstances between the two points in time. Concerning long distance movers, the data need to be interpreted as characteristics of persons who recently moved to the study areas over greater distance.

- Low status groups are generally underrepresented in postal questionnaires. Thus, the social profile of the investigated groups might be partly affected by the research design.

\section{$4 \quad$ Empirical results}

\subsection{Characteristics of commuters with a job-related secondary residence}

Socio-demographic characteristics of commuters and long distance movers are categorised by sex in table 1. To what extent socio-structural features of commuters and long-distance movers differ is shown in table 2. For this purpose, logistic regression analyses are employed, in which selected model parameters are estimated by means of group specific models (commuters vs. long-distance movers). In order to represent gender-specific differences, separate regressions are computed for 
Tab. 1: Socio-demographic characteristics of commuters and employed longdistance movers by sex

\begin{tabular}{|c|c|c|c|c|}
\hline & \multicolumn{2}{|c|}{ Commuters } & \multicolumn{2}{|c|}{ Long distance movers } \\
\hline & Men & Women & Men & Women \\
\hline Men's/women's share & $60.6 \%$ & $39.4 \%$ & $50.8 \%$ & $49.2 \%$ \\
\hline Age (mean, standard deviation in brackets) & $38.6(9.7)$ & $34.5(8.3)$ & $35.6(7.9)$ & $34.3(7.8)$ \\
\hline \multicolumn{5}{|l|}{ Marital status ${ }^{1}$} \\
\hline Married & $41.2 \%$ & $31.5 \%$ & $40.9 \%$ & $27.1 \%$ \\
\hline Never married & $52.2 \%$ & $65.2 \%$ & $52.3 \%$ & $61.3 \%$ \\
\hline \multicolumn{5}{|l|}{ Household type ${ }^{1}$} \\
\hline Couple household with children & $30.7 \%$ & $12.4 \%$ & $23.8 \%$ & $13.0 \%$ \\
\hline Couple household without children & $35.8 \%$ & $42.7 \%$ & $36.8 \%$ & $42.8 \%$ \\
\hline Single household & $31.4 \%$ & $43.8 \%$ & $38.0 \%$ & $37.7 \%$ \\
\hline \multicolumn{5}{|l|}{ Partnership status } \\
\hline Living in partnership & $82.5 \%$ & $77.5 \%$ & $74.4 \%$ & $72.3 \%$ \\
\hline Living Apart Together Partnership (LAT) & $16.0 \%$ & $22.5 \%$ & $14.1 \%$ & $16.5 \%$ \\
\hline No stable partnership & $17.5 \%$ & $22.5 \%$ & $26.3 \%$ & $28.1 \%$ \\
\hline \multicolumn{5}{|l|}{ Children in the household } \\
\hline No child & $67.2 \%$ & $87.6 \%$ & $75.3 \%$ & $81.5 \%$ \\
\hline Youngest child $<6$ years & $9.5 \%$ & $5.6 \%$ & $17.7 \%$ & $10.6 \%$ \\
\hline Youngest child $\geq 6$ years & $23.4 \%$ & $6.7 \%$ & $7.0 \%$ & $7.9 \%$ \\
\hline $\begin{array}{l}\text { University/advanced technical college } \\
\text { degree }\end{array}$ & 7110 & 7050 & $723 \%$ & $68.0 \%$ \\
\hline \multicolumn{5}{|l|}{ Occupational position ${ }^{2}$} \\
\hline Low & $4.7 \%$ & $5.6 \%$ & $10.0 \%$ & $10.7 \%$ \\
\hline Qualified & $20.9 \%$ & $28.1 \%$ & $20.8 \%$ & $41.8 \%$ \\
\hline High & $74.4 \%$ & $66.3 \%$ & $69.2 \%$ & $47.4 \%$ \\
\hline $\mathrm{n}$ & 137 & 89 & 430 & 416 \\
\hline
\end{tabular}

1 Not all categories are shown and therefore the sum does not add up to 100 per cent.

2 low qualified = civil servants of lower rank and employees with simple jobs (e.g. sales assistants), blue-collar workers with low skills; qualified = civil servants of middle rank and employees with qualified jobs (e.g. accounting clerks); highly-qualified = civil servants of higher rank and employees with higher qualified jobs (e.g. engineers, research assistants, department chiefs), employees with executive functions (e.g. executive directors); self-employed, freelancer, trainees were appointed to the categories according to their higher education level.

Source: author's calculations

men and women (model 3 and 4). In the regression table the odds ratios are displayed, which indicate the number by which one would multiply the odds of being a commuter (group 1) for each one-unit increase in the independent variable (e.g. the variable ,highly-qualified position' changes from no $=0$ to yes $=1$ ). Consequently, in table 2 odds ratios greater than 1 indicate a greater probability and odds ratios smaller than 1 signify a lower probability of being a commuter compared to a long distance mover (Menard 2002: 56).

As can be taken from the total model 1 in table 2, among respondents with a jobrelated secondary residence there tend to be statistically significantly more men 
than in the comparison sample. This corresponds to the overrepresentation of male commuters reported in the German Microcensus 2004 (see section 2). Moreover, with a mean age of 39 years, male commuters are significantly older than female commuters, their mean age being 35 years - an observation that does not apply to the sample of employed long-distance movers (compare tab. 1). For women, multilocational household organisations are most often found among younger birth cohorts between 1980 and 1971. Men with job-related secondary residences are more strongly represented in older birth cohorts between 1960 and 1951. Concerning the average age, commuters are not distinct from long-distance movers holding other influencing factors constant (see tab. 2).

All in all, living in a partnership is found more frequently among commuters than in the comparison group (see total model 1 and 2 in tab. 2). In separate regressions for men and women (model 3 and 4) this effect cannot be corroborated, yet, the odds ratios point at a lower probability of men and women with a job-related secondary residence not living in a permanent partnership. This result thus justifies

Tab. 2: Logistic regressions on socio-structural characteristics of commuters (group 1) compared to employed long-distance movers (group 0), odds ratios

\begin{tabular}{|c|c|c|c|c|}
\hline & \multicolumn{2}{|c|}{ All respondents } & \multirow{2}{*}{$\begin{array}{c}\text { Men } \\
\text { Model } 3\end{array}$} & \multirow{2}{*}{$\begin{array}{l}\text { Women } \\
\text { Model } 4\end{array}$} \\
\hline & Model 1 & Model 2 & & \\
\hline Sex (women) & $0.737^{*}$ & 0.869 & & \\
\hline Age (years) & 1.010 & 1.007 & 1.007 & 1.009 \\
\hline \multicolumn{5}{|l|}{$\begin{array}{l}\text { Partnership status (Ref: partner, separate } \\
\text { household) }\end{array}$} \\
\hline Partner, shared household & 0.772 & 0.859 & 0.763 & 0.844 \\
\hline No partner & $0.537^{* *}$ & $0.542^{* *}$ & 0.566 & 0.536 \\
\hline \multicolumn{5}{|l|}{ Children in the household (Ref: no child) } \\
\hline Youngest child $<6$ years & $0.309 * * *$ & $0.354^{* * *}$ & $0.383^{* *}$ & $0.248^{* *}$ \\
\hline Youngest child $\geq 6$ years & 1.115 & $2.257^{* *}$ & $2.089 *$ & $0.345^{*}$ \\
\hline $\begin{array}{l}\text { Highly qualified position (Ref: low or qualified } \\
\text { position) }\end{array}$ & $1.486 * *$ & $1.434^{*}$ & 1.204 & $1.674^{*}$ \\
\hline Number of interregional moves (during the last & & & & \\
\hline 10 years) & 1.071 & 1.070 & 0.980 & $1.173^{*}$ \\
\hline Per capita income (stand.) & 0.894 & 0.921 & 0.956 & 0.837 \\
\hline Home-ownership (Ref: renter, sublessee) ${ }^{1}$ & $9.640 * * *$ & $9.906^{* * *}$ & $8.645^{* * *}$ & $12.089 * * *$ \\
\hline Interaction term: sex*youngest child $\geq 6$ years & & $0.187^{* * *}$ & & \\
\hline $\mathrm{n}$ & 1021 & 1021 & 540 & 481 \\
\hline Model quality & & & & \\
\hline Chi-square (df) & $189.68(10)$ & $197.26(11)$ & $111.60(9)$ & $362.62(9)$ \\
\hline-2 Log-Likelihood & 848.016 & 840.437 & 472.746 & 362.623 \\
\hline Mc Faddens $\mathrm{R}^{2}$ & 0.224 & 0.235 & 0.236 & 0.237 \\
\hline
\end{tabular}

Coefficients are significant: ${ }^{* *} p \leq 0.01,{ }^{* *} p \leq 0.05,{ }^{*} p \leq 0.1$

1 Tenure status of commuters refers to the main residence.

Source: author's calculations 
the focusing of previous research on multilocational households on couples. On the other hand, the findings clearly show that not only couples in a shared household, but also couples with a separated household are involved.

It is, after all, every sixth man and almost every fourth woman who live in a LATpartnership and thus in a very complex living arrangement with regard to the spatial arrangement of the residences and the everyday life practices. This especially applies to a very small group of eleven commuters who live in a long-distance LAT-relationship and who commute between all three locations, i.e. their own households and the residence of their partner, over longer distances of at least $50 \mathrm{~km}$. Thus, jobinduced commuting between two residences revealed to be a much more complex way of living than could have been expected from previous research.

Reasons for the surprisingly significant number of commuters in LAT-partnerships cannot be examined in greater detail on the basis of the present sample, however, evidence from the extended interviews suggests that particularly young commuters who are at the beginning of their occupational career live with their partner in separated households in close proximity at their main residence due to lifestyle reasons (e.g. either partner/both partners appreciate to live at the parental home, the partners have not known each other long enough). Instead, for commuters in long-distance LAT-relationships fix-term contracts are noticeable according to which the re-migration to the main residence is planned so that the multilocational household organisation is of temporary duration or the complex living arrangement is a temporary solution until the partners will find (again) jobs in one area.

Further prominent distinctive features of commuters and long-distance movers are accounted for by the existence of children in the household and the age of the youngest child. Almost one third of the men with a job-related secondary residence live in households with children. For women, however, commuting between two residences for job-reasons is to a high degree a childless way of living. Only every eighth lives in a family household. Compared to female long-distance movers, female commuters more often live in a childless household. By contrast, among men the chance/risk that the youngest child living in the household is older than six years is twice as high for male commuters as for long-distance movers in the conditional logit model. At the same time, the existence of older children in the household is an essential feature which distinguishes women from men with a job-related secondary residence as compared to long distance movers, which can be deduced from the interaction term in table 2.

Taken into account the limitations of the sample (see section 3), the findings indicate that job-induced commuting between two residences is a male-dominated way of living, because men also commute in a couple household with (older) children. The findings of numerous migration studies (see section 2), according to which children exert an inhibiting influence on the migration behaviour of households, can only partly be confirmed: Children - no matter of what age - in a household immensely reduce the chance/risk of women to commute, for men, however, the chance to commute is increased by older (school-age) children.

According to age, marital status and type of household, two groups of men can be defined for which job-related secondary residences are relevant: On the one 
hand, these are young, never married and mostly childless men, on the other these are older, married men in a family household. For women, such a distinctive grouping cannot be observed. Married commuters in a post-parental stage, which were analysed by Gerste/ and Gross (1984) as a specific type of dual career couples in the US, are hardly represented both among men and women in the sample. The higher age which was observed in previous studies for persons with a job-related secondary residence is probably related to the fact that due to the confinement of research perspectives to couples and family households the group of married and thus older men was overrepresented among the respondents.

The vast majority of men and women with a job-related secondary residence have a university or advanced technical college/UAS degree (see tab. 1). In this respect, commuters do not differ from long-distance movers, among whom, as expected, high professional qualifications are predominating, too. Thus, both mobile groups are highly selective in terms of their social profile compared to the population average. Moreover, the majority of respondents with a job-related secondary residence work in high professional positions. A quarter of all men and every third woman have a less qualified position. No sex differences are displayed within the group of commuters with regard to occupational positions, while the comparison sample reflects the well-known pattern of gender-specific vertical segregation of the labour market (see among others Fassmann/Meusburger 1997: 200-212, Albrecht 2005, Wimbauer 1999): Having the same educational status, male long-distance movers work in significantly higher qualified positions than women with a long-distance move. Consequently, the chance of a highly-qualified employment of women with a job-related secondary residence is 1.7 times higher in the conditional logit model than of female long-distance movers. The stability of such a group-specific effect is confirmed, if determinants of a highly-qualified occupation of long-distance movers and commuters are analysed together (not shown in tab. 2). Thus, the multilocational living arrangement correlates with high professional positions for women. It also becomes apparent that both men with a job-related secondary residence and male long distance movers predominantly work in higher positions and that male commuters do not constitute a group with a yet higher professional qualification. Corresponding to the higher qualified employment, women with a job-related secondary residence - compared to female long-distance movers - tend to display a higher interregional mobility, as measured by the number of interregional moves during the last ten years.

\subsection{Personal motives and context conditions}

Asked for the main reason for a job-related secondary residence, most respondents name own occupational reasons (see tab. 3). Corresponding to the younger age of the female commuters is the fact that starting professional life has a greater importance for the establishment of a secondary residence for women than for men (not shown in tab. 3). More than every third woman has moved to the investigated areas because of her career entries. Male commuters are, due to the significant group of older commuters in a family household, at the beginning of their professional ca- 
Tab. 3: $\quad$ Principal reason for a job-related secondary residence by sex and household type (in rounded column percentages)

\begin{tabular}{lrcrrrr}
\hline & \multicolumn{3}{c}{ Male commuters } & \multicolumn{3}{c}{ Female commuters } \\
& All & $\begin{array}{c}\text { Couple/ } \\
\text { family } \\
\text { household }\end{array}$ & $\begin{array}{c}\text { Single } \\
\text { house- } \\
\text { hold }\end{array}$ & All & $\begin{array}{c}\text { Couple/ } \\
\text { family } \\
\text { household }\end{array}$ & $\begin{array}{c}\text { Single } \\
\text { house- } \\
\text { hold }\end{array}$ \\
\hline Own job reasons & 46 & 46 & 45 & 57 & 47 & 67 \\
Reasons of partner & 28 & 35 & $*$ & 19 & 35 & - \\
$\quad$ Thereof: job reasons of partner & 21 & 27 & $*$ & 11 & 20 & - \\
Family reasons (child/parents) & 13 & 13 & 14 & 10 & $*$ & 13 \\
Place/social attachment & 15 & 9 & 27 & 16 & 10 & 23 \\
Other reasons (home-ownership etc.) & 8 & 8 & $*$ & $*$ & $*$ & $*$ \\
$\mathrm{n}$ & 135 & 91 & 44 & 88 & 49 & 39 \\
\hline
\end{tabular}

It was only asked for the main reason for having a job-used secondary residence, however, multiple answers were counted in 17 cases.

* Number of cases is four or less and is therefore not reported.

Source: author's calculations

reers less frequently than female commuters, and thus have registered a secondary residence in the respective investigated areas mainly due to changing their employers (41 per cent).

In general, the establishment of another dwelling is only infrequently related to the acceptance of a job after unemployment, which for ten per cent of the men and nine per cent of the women was the primary motive for a move-in to the job-related secondary residence in the investigated areas. Six respondents established a secondary residence because of a probation period. This low percentage, however, is most likely due to the sample design (see section 3 ) as only few commuters might register a secondary residence for the short period of probation (generally 3-6 months). The questionnaire also contains retrospective questions about a former job-used secondary. Among respondents that once had a secondary residence for job reasons during the past ten years $(n=107)$ a respectable percentage of one fourth reported the unsecure phase at the beginning of a new job as principal reason for the commuting between two residences at that time. This speaks for the importance of multilocational household organisations as transitional solutions and "springboard for migration" (Hunt 2006) at career entry or in the case of employer change. The duration of the living arrangement will be further elaborated in section 4.3.

\section{Atypical employment and commuting}

The career entries of female commuters frequently coincide with fix-term employment. Taken together, 26 per cent of women and 18 per cent of the male commuters have a fix-term contract. After controlling for age, commuters do not significantly 
more often have a fix-term contract than long-distance movers, of whom 18 per cent of the men and 20 per cent of the women have a fix-term employment. If, however, the fix-term employment rate in Germany (involving all dependent employees) is considered, which, in 2008, was 8.9 per cent (Grau 2010), the findings indicate that the rising importance of fix-term employment impact contemporary migration patterns. The generally high importance of fix-term contracts in both groups of inmigrants relates to age, occupational qualification and spatial structures: Employed migrants are generally younger than all persons employed, the proportion of young professionals in the sample is high, and the portion of the service sector is above average in the selected metropolises (cf. Grau 2010; Albrecht 2005).

Commuters with a fix-term contract are almost exclusively employed in highlyqualified positions. Among women, too, fix-term employment is frequently related to part-time work. Altogether, every fifth female commuter has two households because of (or despite) part-time work. Male commuters, however, like long-distance movers, are rarely employed in part-time jobs, which correspond to the genderspecific flexibilisation of working time in Germany in general (Holst/Schupp 2008: 123).

Female part-time employed commuters predominantly work in various positions in health care and social services or as highly-qualified employees in research and science. In their social profile, they deviate from the "typical" female part-time employment in that they are most often single women at the beginning of their professional careers, and not women returning to work, living in a partnership and having children (Sacher 1998, Albrecht 2006).

The significant number of highly-qualified commuters in atypical forms of employment (fix-term contracts and/or part-time employment) suggests that the ambivalence of social upward mobility and insecure employment conditions speak in favour of a temporary multilocational household organisation. In some branches like research and sciences, art and culture, and automobile industries respondents are confronted with sequences of fix-term contracts or short-term assignments in various cities and therefore decide to maintain the primary residence ("the place where one wants to live") and subsequently move on to varying working places if the (material and immaterial) commuting costs in terms of commuting distance/time, expenses for travelling and housing, and length of stay at the primary residence are not too high. Concerning part-time employment, commuting distance has a strong impact on the mobility decisions of female commuters: Part-time employed women commute between both residences over significantly shorter distances than fulltime employed female commuters (median commuting distance $107 \mathrm{~km}$ vs. 283 $k m, p \leq 0.05)$. This suggests that women with a part-time job offer either opt for migration or spatial immobility (i.e. refusing job offer) if the commuting distance is evaluated as too great, which often means a maximum of $100-150 \mathrm{~km}$.

\section{Commuting partnerships and families}

As shown in table 3, for more than every third in a couple household (with or without children), motives of the partner are decisive for the choice of a secondary resi- 
dence. Here, the occupation of the partner plays a particular role. At least more than every fourth man and every fifth woman in a couple household (with or without children) name occupational reasons of the partner as a main motive for the establishment of a secondary residence. These data clearly demonstrate the modernisation of traditional gender-specific migration roles in couple households and suggest that the multilocational household organisation was chosen in order to avoid tied partner conflicts that would have occurred in the case of migration or spatial immobility.

However, this mobile living arrangement might be preferred in couple/family households as long as the (material and immaterial) commuting costs do not exceed the migration costs. The findings show that the possibility to prolong the time spent at the main residence beyond the weekend until Monday mornings is an important precondition for the commuting. Further it can be suggested that especially men with above-average weekly work hours opt for migrating with the whole household to establishing a job-used secondary residence the higher the commuting distance between both accommodations is and thus the less time can be spend at the family residence. For example, an executive manager with more than 50 work hours had been commuting weekly between the firm's headquarter in Munich and Stuttgart (ca. $220 \mathrm{~km}$ ) for four years. The multilocational household organisation was feasible for him and his family since the moderate travel distance, which he often covered by car at night in order to reduce travel time, in combination with flexible appointments at the firm's headquarter, allowed for longer-lasting stays at the family household. However, when he was dislocated to Dusseldorf and thus the commuting distance increased to about $500 \mathrm{~km}$, he and his wife, who pursues her own career as a surgeon, now decided to move their main residence to Dusseldorf. Spatial immobility - i.e. the refusal of the job offer - is not an option in this particular case as clear career steps, which are related to interregional and international dislocation, are given in his working field that is focused on organisational careers, i.e. job promotion within one organisation/employer (for a classification of career strategies see Savage 1988).

As indicated by the great importance of job reasons of the female partner for the establishment of a secondary residence by men in a couple/family household, the late modern manifestation of job-induced commuting between two accommodations for male commuters shows on the basis of the employment arrangement in households. Compared to employed long-distance movers, male commuters more frequently live in a dual earner household (see tab. 4).

With respect to the occupational position of female partners the employment arrangements of male commuters in partnerships are, however, far less modernised (see tab. 4). Although they more often live in a household in which both partners are employed than long-distance movers, their female partners for the most part "only" work in qualified positions. Almost half of the male commuters with an employed partner are employed in positions of a higher qualification than those of their partners. Compared to long-distance movers in couple/family households, the percentage of dual career households in which both partners are employed in highly-qualified positions is thus somewhat lower for male commuters (23\% vs. $26 \%$ ). The 
Tab. 4: Employment arrangements by mobile living form and sex (in rounded column percentages)

\begin{tabular}{|c|c|c|c|c|}
\hline & \multicolumn{2}{|c|}{ Commuters } & \multicolumn{2}{|c|}{$\begin{array}{l}\text { Employed long } \\
\text { distance movers }\end{array}$} \\
\hline & Men & Women & Men & Women \\
\hline \multicolumn{5}{|l|}{ A) All respondents } \\
\hline Dual earner household & 60 & 67 & 48 & 64 \\
\hline Dual career household ${ }^{1}$ & 15 & 26 & 15 & 21 \\
\hline $\mathrm{n}$ & 134 & 89 & 424 & 409 \\
\hline \multicolumn{5}{|c|}{ B) Respondents in couple/family households } \\
\hline Dual earner household & 73 & 86 & 62 & 88 \\
\hline Dual career household ${ }^{1}$ & 23 & 47 & 26 & 39 \\
\hline $\mathrm{n}$ & 88 & 49 & 255 & 228 \\
\hline \multicolumn{5}{|c|}{ C) Respondents in couple/family households with an employed partner } \\
\hline \multicolumn{5}{|c|}{ Occupational position of the partner } \\
\hline Low & 5 & 7 & 13 & 8 \\
\hline Qualified & 57 & 17 & 39 & 23 \\
\hline High & 38 & 76 & 48 & 69 \\
\hline \multicolumn{5}{|c|}{ Respondent's occupational position compared to the one of the partner. His/her rank is ... } \\
\hline Lower & 9 & 24 & 7 & 27 \\
\hline Equal & 46 & 64 & 64 & 63 \\
\hline Higher & 46 & 12 & 29 & 10 \\
\hline $\mathrm{n}$ & 59 & 42 & 150 & 195 \\
\hline
\end{tabular}

1 Both partners work in highly-qualified positions.

Source: author's calculations

disparity in the employment arrangement of households of male commuters and male long-distance movers presumably relates to the location of the couple's/famiIy's main residence in rural/structurally weak areas (including Eastern Germany) and thus in regions where lower qualified jobs are dominating and possibilities for job promotion in situ are limited. Accordingly, Fromhold-Eisebith and Schrattenecker (2006) note a rising concentration of highly-qualified jobs in core cities in metropolitan areas particularly in Western Germany and thus in areas where the interviewed male long-distance movers are living with their partners/families. The result might also be partly due to the research design since the household situation applies to the time of the interview and not to the point in time when the respondents moved to the respective city (see section 3 ). That is, long-distance movers could have been living in single households when they moved to the study areas.

The employment arrangement of households of women with a job-related secondary residence resembles that of female employed long-distance movers to a great degree (see tab. 4). The partners are most often employed in highly-qualified positions, female commuters who share a household with the partner most often live with a partner of the same professional qualification or in almost half of the cases even as dual career couple (see operationalisation in footnote 1 in tab. 4). 
The gender-specific differences in the employment arrangements in couple/family households within the group of commuters are all the more clear: Under control for age, of all respondents being in a couples household with or without children significantly more women than men live in a household in which both partners are employed in highly-qualified positions. Accordingly, compared to male commuters, women with two accommodations for job reasons more frequently commute between cities with 100,000 inhabitants and more $(50 \% \text { vs. } 31 \% \text {, adjusted } p \leq 0.05)^{2}$ and thus between areas where highly-qualified jobs are concentrated. Co-location problems of highly-qualified couples thus seem to be an important context condition for a multilocational household organisation of women.

\section{Commuters in single households}

Apart from job reasons, commuters in single households name attachment with the place or region, social contacts and friends as well as family reasons (in particular parents) as primary reasons for maintaining two households more frequently than other commuters (see tab. 3). Especially for single women, the care for parents including assistance with the owned home, and the attachment to the family house and the attached garden reveal to be of special importance in this respect. In fact, more than every fourth female commuter in a single household lives in the proprietaries of her parents/one parent at the main residence and presumably most likely also lives there with her parents or one parent. This living situation applies less frequently to male commuters (15\%). This corresponds to the remarkable differences between men and women with job-used secondary residences with regard to their stage of household/family life cycle (see tab. 1 and 2). Demographic and gerontological research shows that it is most frequently women that take care for their elderly parents (see for Germany amongst others Bundesministerium für Familie, Senioren, Frauen und Jugend 1998). Against the background of the rapid aging of late modern societies one might therefore suggest that multilocational household organisations of women in single households will not be a marginal phenomenon in the future.

Concerning partnership, it can be noted that both women and men living in homes owned by their parents frequently live in a LAT-partnership at the main residence close to the partner's residence. On the one hand, this might speak in favour of multilocational household organisations being a temporary living arrangement in a pre-family stage that will be terminated either by re-migration to the main residence or by complete migration to the secondary residence in the case of a stabilised partnership status. On the other hand, it can be observed that the living apart together was terminated during commuting between two accommodations by moving in together with the partner at the main residence. In this particular case the multilocational way of living has become a long-term solution due to the part-

2 Control variables: age (in years), number of persons in the household, fix-term contract, homeownership at the main residence. 
ner's place attachment (family, social relations/engagement, preferences for nature/ countryside) and his professional career strategies.

\section{Commuters and home-ownership}

Altogether, a good half of the women and men own their homes at their main residence (including homes owned by the parents/one parent). However, despite the high proportion of residential properties at the main residence, attachment due to home-ownership is named only in a few cases as the primary reason for a secondary residence. Since the main reason for secondary residences was asked for, it must be assumed that home-ownership is much more of secondary importance for the establishment of a job-related secondary residence, which is subordinated to familial and emotional bonds: As is shown in table 2, housing tenure has a significant influence on decisions related to mobility (commuting vs. migrating). This finding is additionally confirmed by the analysis of the subjective attitudes towards establishing a job-related secondary residence in the total sample (i.e. all respondents in the study areas). Of all interviewed employees $(n=1688)$, the statement: "Being offered a job in another city/region I would decide for a secondary dwelling/accommodation at the new place of work and maintain my main residence", was significantly more often agreed on by home-owners than by renters (adjusted $p \leq 0.01$ ). ${ }^{3}$

From this it follows that owning the home is also a relevant influential factor on the decision to prefer commuting to migration with the complete household and that multilocational household organisations are a frequently practiced option to combine job-related geographical mobility demands with the (material and emotional) attachment to the owned home.

\subsection{Duration of the living arrangement}

As it was noticed earlier, commuting between two accommodations for job reasons is frequently of temporary duration due to fix-term contracts, short-assignments, and probation periods. Moreover, correlations between the duration of the living arrangement and socio-demographic characteristics of commuters are relevant.

According to the commuters' evaluation of the duration of their current multilocational living arrangement - measured in a standardised way by using four items: permanent, long-lasting but not permanent, temporally limited, no statement possible - the multilocational household organisation is rather a temporally limited living arrangement for the group of younger men in a childless couple household. If a (school-aged) child lives in the household, the multilocational way of life of men is partly a long-term arrangement. For some of those the commuting will be an al-

3 Control variables: age (in years), shared household with the partner, children in the household, highly-qualified position. 
ternative way of living at least until the children will have finished high school and left home or until both partners will have retired. The place attachment due to older children thus does not only affect men's propensity to commute, but also the permanence of the form of living. As for women, the commuting is not an alternative to migration for men with young (pre-school) children. Thus, it can be observed that male commuters try to terminate the multilocational household organisation if they and their partners are expecting a child.

Women in a couple/family household predominantly try to limit the multilocational way of life to a particular period, here, especially for married women commuting is only a temporary solution. Both for women and men it can be noticed that the younger commuters are the shorter is the period of time they are planning to practice a multilocational household organisation for job reasons. For young commuters, the multilocational way of living is due to the career entry and to the first steps in building an occupational career whereas a short-term commuting period is intended right at the beginning.

Taken together, the investigated commuters have been leading a multilocational life for a median time of 3 years. ${ }^{4}$ Every fifth has lived in a multilocational household for less than a year. Another quarter of all respondents has been living as a commuter for at least 5 years. It has to be noticed, however, that the duration of the multilocational household organisation is influenced by the sample design, as was already discussed in section 3 .

\section{$5 \quad$ Summary and conclusion}

The findings clearly show that commuters with two accommodations for job reasons are a heterogeneous group. As could be expected from previous research, living in a partnership is of high importance. However, considering the household and partnership situation, various types apply to commuters:

- shared households without children,

- family households,

- living alone as single,

- living alone in separated households with the partner (i.e. without a shared residence) at close proximity or at greater distances (long-distance LAT-partnership),

- living as single or LAT in the owned home of the parents or one parent at the main residence.

This variety in individual living circumstances indicates that future research on multilocational household organisations for job reasons should not only focus on couple households (with or without children), but also consider more complex mul-

$4 \mathrm{~N}=219$, standard deviation $=3.17$. 
tilocational forms and the living arrangement and commuting behaviour of singles and persons living alone. Given the progressing pluralisation of living arrangements and aging of our society, one might expect a rising importance of 'non-traditional' household and partnership compositions of commuters in late modern societies.

The results show that for a proper investigation of multilocational household organisations for job reasons gender-specific differences must be taken into consideration. The crucial differences can be traced back to the household/family life cycle, i.e. age, marital status, and children. The younger, most often single and childless women and men with a job-related secondary residence are comparable to Gross' "adjusted" type of commuting (Gross 1980). However, these are not only women and men who live together with their partners in a household, but couples who live together apart in separate households are also concerned. The older commuters, who mostly live in a family household, most closely correspond to Gross' "established" type of commuting. This form of commuting is strongly associated with male commuters. The higher proportion of men among commuters - also compared to interregional moves with the whole household - can thus be traced back to this group of commuters.

For young commuters it can be noticed that the multilocational living arrangement often refers to the career entry, which frequently goes hand in hand with atypical employment (fix-term jobs, part-time employment). The flexibilisation of post-industrial labour markets therefore does not only result in an increasing first job instability for young men and women (Booth et al. 1999; Buchholz/Kurz 2008) but also contributes to changes in the mobility behaviour of young employed. The constraints on in-moves to the place of work and the abandonment of the main household will be too high due to such insecure employment conditions. Insecure employment conditions together with the high importance that is attached to the time spent with the partner explain why a multilocational household organisation is most frequently of temporary duration for young commuters. It is to be expected that with an increasing flexibilisation of labour markets multilocational household organisations will gain further importance in the future. For older ('established') commuters, commuting between two accommodation is - compared to young commuters - a partly longer-lasting period due to the place attachment of the partner and/or the children and, mostly subordinated, because of the (material and immaterial) obstacles of selling the owned home.

Consequently, commuting between two accommodation is an option to migration and spatial immobility especially for men in a family household with older (school-aged) children. In contrast, the finding that female commuters predominantIy live in childless households suggests that for women with children - regardless the children's age - commuting between two residences is less suited for combining career and family and is therefore less frequently considered as an alternative form of living in case of job-induced geographical mobility demands. The comparison analyses indicate that both men and women with younger (pre-school) children prefer migration with the complete household to the establishment of a job-used secondary residence. 
The majority of male and female commuters in the sample work, as hypothesised, in high occupational positions. The hypotheses that dual earner households and the place attachment of working partners are crucial factors for the commuting between two residences can also be confirmed. However, dual career households in which both partners are employed in highly-qualified positions generally apply only to a minority of commuters. Owning the home has become a subordinated motive for commuting but is still a relevant influencing factor on the decision to prefer commuting to migration.

To conclude, late modern characteristics of job-induced multilocational living arrangements are living in dual earner households for male and for female commuters. On the other hand, the fact that in a family household men commute more frequently than women must be taken as an indicator of a conventionalised genderspecific division of labour in the domain of child-rearing that again reveal traditional gender-specific mobility decisions. This is supported by the circumstance that men with a job-related secondary residence live in a dual career household less frequently than female commuters.

In section 3, notes concerning the sample design of the present study were discussed critically. Given the progressing suburbanisation and the tight housing markets in Munich and Stuttgart, future research on multilocational household organisations for job reasons should be extended to metropolitan areas as especially in regions that have experienced long-lasting suburbanisation processes commuters could select the peri-urban areas - directly or on a "detour" via the core city - as the location of a job-related secondary residence. Furthermore, the applied comparative approach proved to be helpful in order to investigate specific characteristics of commuters with a job-used secondary residence in relation to long-distance movers. Thus, assumptions on who prefers commuting to migrating with the complete household could be concluded in the context of the present study. Since only inmovers in selected cities were included in the sample, only some hypothetical answers could be given in the present research to the question who prefers spatial immobility to commuting under which circumstances. However, spatial immobility could be an option alongside commuting or migration especially for dual earner families if the negative effects of tied migration or the commuting costs would be too high (Bailey/Blake/Coke 2004). Future research that investigates mobility decisions in a wider context including spatially immobility, migration (with the whole household) and commuting between two residences may prove valuable for explaining the low migration rate of dual earner households. A random sample survey that aims to provide more useful insights into contemporary mobile living arrangements therefore should draw a sub-sample of spatially immobile residents (who have lived, for example, ten years and longer in the selected area) in addition to the selected spatially mobile groups of the present study.

I would like to thank two anonymous referees for helpful comments and suggestions. The postal survey was funded by the Ministry of Innovation, Sciences, Research and Technology of the German federal state of North Rhine-Westphalia 
and conducted at the Department of Gender Studies and Housing Research of the School of Spatial Planning at TU Dortmund.

\section{References}

Albrecht, Susanne, 2005: Arbeitsmärkte in großstädtischen Agglomerationen. Auswirkungen der Deregulierung und Flexibilisierung am Beispiel der Regionen Stuttgart/Lyon. Wirtschaftsgeographie 29. Munster: Lit-Verlag

Albrecht, Susanne, 2006: Flexibilisierung der Arbeit. In: Institut für Länderkunde (ed.): Nationalatlas Bundesrepublik Deutschland 7: Arbeit und Lebensstandard. Heidelberg/ Berlin: Spektrum Akademischer Verlag: 50-53

Anderson, Elaine A.; Spruill, Jane W., 1993: The Dual-Career Commuter Family: A Lifestyle on the Move. In: Marriage \& Family Review 19,1/2: 131-147

Bailey, Adrian J.; Blake, Megan K.; Cooke, Thomas J., 2004: Migration, care, and the linked lives of dual-earner households. Environment and Planning A 36,9: 1617-1632

Beck, Ulrich, 1986: Risikogesellschaft. Auf dem Weg in eine andere Moderne. Frankfurt on the Main: Suhrkamp

Beck, Ulrich, 1999: Schöne neue Arbeitswelt - Vision „Weltbürgergesellschaft". Frankfurt on the Main/New York: Campus Verlag

Behnen, Tobias; Ott, Erich, 2006: Arbeitskräftemobilität - Fernpendler und ihre Lebenssituation. In: Leibnitz-Institut für Landeskunde (ed.): Nationalatlas Bundesrepublik Deutschland 7: Arbeit und Lebensstandard. Heidelberg/Berlin: Spektrum Akademischer Verlag: 56-59

Bertaux-Wiame, Isabel, 2006: Conjugalité et mobilité professionnelle: le dilemme de l'égalité. In: Bertaux-Wiame, Isabel; Tripier, Pierre (eds.): Les intermittents du foyer. Couples et mobilité professionnelle. Cahiers du Genre 41. Paris: L'Harmattan: 49-73

Bertaux-Wiame, Isabel; Tripier, Pierre, 2006: Les intermittents du foyer ou les arrangements entre membres des couples qui travaillent loin l'un de l'autre. In: BertauxWiame, Isabel; Tripier, Pierre (eds.): Les intermittents du foyer. Couples et mobilité professionnelle. Cahiers du Genre 41. Paris: L'Harmattan: 11-22

Bielby, William T.; Bielby, Denise D., 1992: Gender-Role Beliefs and Reluctance to Relocate for a Better Job. American Journal of Sociology 97,5: 1241-1267

Blossfeld, Hans-Peter; Drobnič, Sonja, 2001: Theoretical Perspectives on Couples' Careers. In: Blossfeld, Hans-Peter; Drobnič, S. (eds.): Careers of Couples in Contemporary Societies. From Male Breadwinner to Dual Earner Families. New York: 16-50

Bogai, Dieter; Seibert, Holger; Wiethölter, Doris, 2006: Pendlerbericht Berlin-Brandenburg 2005. Weiter zunehmende Mobilität als Strategie gegen Erwerbslosigkeit. IAB regional $1 / 2006$. Nürnberg

Bonnet, Estelle; Collet, Beate; Maurines, Béatrice, 2006: Carrière familiale et mobilité géographique professionnelle. In: Bertaux-Wiame, Isabel; Tripier, Pierre (eds.): Les intermittents du foyer. Couples et mobilité professionnelle. Cahiers du Genre 41. Paris: L'Harmattan: 75-97

Bonß, Wolfgang; Kesselring, Sven; Weiß, Anja, 2004: "Society on the move“ Mobilitätspioniere in der Zweiten Moderne. In: Beck, Ulrich; Lau, Christoph (eds.): Entgrenzung und Entscheidung: Was ist neu an der Theorie reflexiver Modernisierung? Frankfurt on the Main: Suhrkamp: 258-280 
Booth, Alison L.; Francesconi, Marco; Garcia-Serrano, Carlos, 1999: Job tenure and job mobility in Britain. Industrial and Labor Relations Review 53: 43-70

Breyer, Friedrich, 1970: Die Wochenendpendler des Bayerischen und Östlichen Oberpfälzer Waldes. Eine wirtschaftsgeographische Regionalstudie unter besonderer Berücksichtigung des Einpendlerzentrums München. WGI-Berichte zur Regionalforschung Munich

Buchholz, Sandra; Kurz, Karin, 2008: A new mobility regime in Germany? Young people's labor market entry and phase of establishment since the mid-1980s. In: Blossfe/d, Hans-Peter; Buchholz, Sandra; Bukodi, Erzsebet; Kurz, Karin (eds.): Young workers, globalization and the labour market. Comparing early working life in eleven countries. Cheltenham (UK)/Northhampton (MA, USA): 51-76

Büchel, Felix, 2000: Tied Movers, Tied Stayers: The Higher Risk of Overeducation among Married Women in West Germany. In: Gustafsson, Siv S.; Meulders, Danièle E. (eds.): Gender and the Labour Market. Econometric Evidence of Obstacles to Achieving Gender Equality. London: 133-146

Bundesministerium für Familie, Senioren, Frauen und Jugend (BMFSFJ), 1998: Zweiter Altenbericht. Wohnen im Alter. Bonn: 94-127

Bunker, Barbara B.; Zubek, Josephine. M.; Vanderslice, Viginia J.; Rice Robert W., 1992: Quality of Life in Dual-Career Families: Commuting Versus Single-Residence Couples. In: Journal of Marriage and the Family 54,2: 399-407

Clorius, Sina, 2006: Gelobtes Land im Norden. Neue Chancen für Arbeitslose in Schleswig-Holstein: Viele suchen ihr Glück als Gastarbeiter in Dänemark. Die Zeit 41: 15

DaVanzo, Julie, 1981: Repeat Migration, Information Costs, and Location-Specific Capital. Population and Environment 4,1: 45-73

Fassmann, Heinz; Meusburger, Peter, 1997: Arbeitsmarktgeographie. Erwerbstätigkeit und Arbeitslosigkeit im räumlichen Kontext. Stuttgart: Teubner

Fröhlich, Diana; Detering, Michael, 2010: Liebe plus Karriere. Die Zeit online, download: http://www.zeit.de/karriere/2010-01/partnersuche-job-buero

Fromhold-Eisebith, Martina; Schrattenecker, Wolfgang, 2006: Qualifikationsstruktur der Beschäftigten im Wandel. In: Institut für Länderkunde (ed.): Nationalatlas Bundesrepublik Deutschland 7: Arbeit und Lebensstandard. Heidelberg/Berlin: 38-39

Gerstel, Naomi; Gross, Harriet E., 1984: Commuter Marriage. A Study of Work and Family. New York/London: Guilford Publications

Gräbe, Sylvia; Ott, Erich, 2003: „... man muss alles doppelt haben“. Wochenpendler mit Zweithaushalt am Arbeitsort. Soziologie: Forschung und Wissenschaft 6. Munster: Lit-Verlag

Grau, Andreas, 2010: Befristete Beschäftigung: Jeder elfte Vertrag hat ein Verfallsdatum. STATmagazin, 16th March 2010

Green, Anne E., 1995: The Geography of Dual Career Households: A Research Agenda and Selected Evidence from Secondary Data Sources for Britain. International Journal of Population Geography 1,1: 29-50

Green, Anne E.; Hogarth, Terence; Shackleton, Ruth, 1999: Long distance living. Dual location households. Bristol: Policy Press

Gross, Harriet E., 1980: Dual-Career Couples Who Live Apart: Two Types. In: Journal of Marriage and the Family 42,3: 567-576 
Hackl, Maria, 1992: Pendler - Räumliche Bindung und der Zwang zur Mobilität. Die Trennung von Wohnort und Arbeitsort am Beispiel von Wochenendpendlern im Bayerischen Wald. Erlangen/Nuremberg

Hardill, Irene, 2002: Gender, Migration and the Dual Career Household. London/New York: Routledge

Hogarth, Terence; Daniel, William W., 1988: Britains New Industrial Gypsies. Long Distance Weekly Commuters. PSI Research Report 688. London: Policy Studies

Holst, Elke; Schupp, Jürgen, 2008: Situationen und Erwartungen auf dem Arbeitsmarkt. In: Statistisches Bundesamt, Gesis-Zuma, WZB (ed.): Datenreport 2008. Bonn: 122-128

Hunt, Jennifer, 2006: Staunching Emigration From East Germany: Age and the Determinants of Migration. Journal of European Economic Association 4,5: 1014-1037

Jürges, Hendrik, 1998a: Einkommen und berufliche Situation von Doppelverdienern nach Umzügen. Mitteilungen aus der Arbeits- und Berufsforschung 31,2: 234-243

Jürges, Hendrik, 1998b: Beruflich bedingte Umzüge von Doppelverdienern. In: Zeitschrift für Soziologie 27,5: 358-377

Jürges, Hendrik, 2006: Gender ideology, division of housework, and the geographic mobility of families. In: Review of Economics of the Household 4,4: 299-323

Junker, Serena, 1992: Wochenendpendler aus dem Landkreis Freyung- Grafenau. Theoretische Annäherung und qualitative Einzeluntersuchungen. Beiträge zur Arbeitsmarkt- und Berufsforschung des IAB 164. Nuremberg

Kalter, Frank, 1998: Partnerschaft und Migration. Zur theoretischen Erklärung eines empirischen Effekts. In: Kölner Zeitschrift für Soziologie und Sozialpsychologie 50,2: 283-309

Levin, Irene, 2004: Living Apart Together: A New Family Form. In: Current Sociology 52, 2: $223-240$

Limmer, Ruth; Schneider, Norbert F., 2008: Studying Job-Related Spatial Mobility in Europe. In: Schneider, Norbert F.; Meil, Gerardo (eds.): Mobile Living Across Europe I. Relevance and Diversity of Job-Related Spatial Mobility in Six European Countries. Opladen/Farmington Hills, MI: Barbara Budrich Publishers: 13-45

Lutz, Burkart; Kreuz, Dieter, 1968: Wochenendpendler. Eine Extremform des Erwerbsverhaltens in wirtschaftlich schwachen Gebieten, dargestellt am Beispiel Ostbayerns. Munich: hektogr. Bericht

Menard, Scott, 2002: Applied Logistic Regression Analysis. $2^{\text {nd }}$ edition, Sage University Papers Series on Quantitative Applications in the Social Sciences 07-106. Thousand Oaks, CA: Sage

Mincer, Jacob, 1978: Family Migration decisions. Journal of Political Economy 86,5: 749-773

Mulder, Clara H, 1993: Migration Dynamics. A Life Course Approach. Amsterdam

Mulder, Clara H.; Hooimeijer, Pieter, 1999: Residential Relocations in the Life Course. In: Van Wissen, Leo J. G.; Dykstra, Pearl A. (eds.): Population Issues. An Interdisciplinary Focus. New York etc.: Springer: 159-186

Peck, Jamie, 1996: Workplace: The Social Regulation of Labor Markets. New York: Gilford Press

Reuschke, Darja, 2010: Multilokales Wohnen. Raum-zeitliche Muster multilokaler Wohnarrangements von Shuttles und Personen in einer Fernbeziehung. Wiesbaden: VS-Verlag 
Sacher, Matthias, 1998: Berufseinstieg - gestern und heute. Ein Kohortenvergleich. In: Friedrichs, Jürgen (ed.): Die Individualisierungs-These. Opladen: Leske + Budrich: 165-180

Savage, Mike, 1988: The missing link? The relationship between spatial mobility and social mobility. The British Journal of Sociology 39,4: 554-577

Schneider, Norbert F.; Limmer, Ruth, 2008: Job Mobility and Living Arrangements. In: Canzler, Weert; Kaufmann, Vincent; Kesselring, Sven (eds.): Tracing Mobilities. Towards a Cosmopolitan Perspectives. Aldershot: Ashgate: 119-139

Schneider, Norbert F.; Limmer, Ruth; Ruckdeschel, Kerstin, 2002: Berufsmobilität und Lebensform. Schriftenreihe des Bundesministeriums für Familie, Senioren, Frauen und Jugend 208. Stuttgart

Schneider, Norbert F.; Meil, Gerardo, 2008: Mobile Living Across Europe I. Relevance and Diversity of Job-Related Spatial Mobility in Six European Countries. Opladen/ Farmington Hills, MI: Barbara Budrich Publishers

Sennett, Richard, 2000: Der flexible Mensch. $2^{\text {nd }}$ edition. Berlin: btb Verlag

Sjaastad, Larry A., 1962: The Costs and Returns of Human Migration. Journal of Political Economy 70,5: 80-93

Smits, Jeroen, 2001: Career Migration, Self-selection and the Earnings of Married Men and Women in the Netherlands, 1981-93. Urban Studies 38,3: 541-562

Smits, Jeroen; Mulder, Carla H.; Hooimeijer, Pieter, 2003: Changing gender roles, shifting power balance and long-distance migration of couples. Urban Studies 40,3: 603-613

Song-Chul, Kim, 2001: „Weekend Couples" among Korean Professionals: An Ethnography of Living Apart on Weekdays. Korea Journal [http://www.ekoreajournal.net/ archive]

Statistisches Bundesamt, 2002: Statistisches Jahrbuch 2002. Wiesbaden

Statistisches Bundesamt, 2005: Leben und Arbeiten in Deutschland. Mikrozensus 2004. Wiesbaden

Statistisches Bundesamt, 2009: Statistisches Jahrbuch 2009. Wiesbaden

Van der Klis, Marjolijn, 2008: Continuity and change in commuter partnerships: avoiding or postponing family migration. GeoJournal 71: 233-247

Van der Klis, Marjolijn; Mulder, Clara H., 2008: Beyond the trailing spouse: the commuter partnership as an alternative to family migration. In: Journal of Housing and the Built Environment 23,1: 1-19

Van Ommeren, Jos N.; Rietveld, Piet; Nijkamp, Peter, 1998: Spatial Moving Behavior of Two-Earner Households. Journal of Regional Science 38,1: 23-41

Vielhaber, Christian, 1987: Sekundäre Aktionsräume von Wochenpendlern. In: Husa, Karl; Vielhaber, Christian; Wohlschlägl, Helmut (eds.): Beiträge zur Bevölkerungsforschung. Abhandlungen zur Geographie und Regionalforschung 1. Vienna: 163-188

Vignal, Cécile, 2006: Devenir ,célibataire géographique'? Arbitrages conjugaux et familiaux suite à la délocalisation d'une usine. In: Bertaux-Wiame, Isabel; Tripier, Pierre (eds.): Les intermittents du foyer. Couples et mobilité professionnelle. Cahiers du Genre 41. Paris: L'Harmattan: 139-157

Wagner, Michael, 1989: Räumliche Mobilität im Lebensverlauf. Eine empirische Untersuchung sozialer Bedingungen der Migration. Stuttgart: Enke 
Weiske, Christine; Petzold, Knut; Zierold, Diana, 2009: Multilokale Haushaltstypen. Bericht aus dem DFG-Projekt “Neue multilokale Haushaltstypen" (2006-2008). In: Informationen zur Raumentwicklung 1/2: 67-75

Wimbauer, Christine, 1999: Organisation, Geschlecht, Karriere. Fallstudien aus einem Forschungsinstitut. Studien zur Wissenschafts- und Organisationssoziologie 1. Opladen: Leske + Budrich

Winfield, Fairlee E., 1985: Commuter Marriage. Living Together, Apart. New York: Columbia University Press

Wood, Gerald, 2008: Multilokale Haushalte in spätmodernen Gesellschaften. (manuscript)

A German translation of this authorised original article by the author is available under the title "Berufsbedingtes Pendeln zwischen zwei Wohnsitzen - Merkmale einer multilokalen Lebensform in der Spätmoderne", DOI 10.4232/10.CPoS-2010-04de or URN urn:nbn:de:bib-cpos-2010-04de6, at http://www.comparativepopulationstudies.de.

Dr. Darja Reuschke( $\bowtie)$, University of Trier, Institute of Geography \& Geosciences,

Department of Human and Regional Geography, 54286 Trier.

E-Mail: reuschke@uni-trier.de 


\section{Comparative Population Studies - Zeitschrift für Bevölkerungswissenschaft}

wWw.comparativepopulationstudies.de

ISSN: 1869-8980 (Print) - 1869-8999 (Internet)

Published by / Herausgegeben von

Prof. Dr. Norbert F. Schneider

Layout and print: Federal Institute for Population Research, Wiesbaden

(Germany)

\section{Managing Editor / Redaktion}

Frank Swiaczny

Copy Editor / Schlußredaktion

Dr. Evelyn Grünheid

\section{Scientific Advisory Board / \\ Wissenschaftlicher Beirat}

Jürgen Dorbritz (Wiesbaden)

Paul Gans (Mannheim)

Johannes Huinink (Bremen)

Dirk J. van de Kaa (Den Haag)

Marc Luy (Wien)

Notburga Ott (Bochum)

Peter Preisendörfer (Mainz)

\section{Board of Reviewers / Gutachterbeirat}

Martin Abraham (Erlangen)

Laura Bernardi (Lausanne)

Hansjörg Bucher (Bonn)

Claudia Diehl (Göttingen)

Andreas Diekmann (Zürich)

Gabriele Doblhammer-Reiter (Rostock)

Henriette Engelhardt-Wölfler (Bamberg)

E.-Jürgen Flöthmann (Bielefeld)

Alexia Fürnkranz-Prskawetz (Wien)

Beat Fux (Zürich)

Joshua Goldstein (Rostock)

Karsten Hank (Mannheim)

Sonja Haug (Regensburg)

Franz-Josef Kemper (Berlin)

Hans-Peter Kohler (Philadelphia)

Michaela Kreyenfeld (Rostock)

Aart C. Liefbroer (Den Haag)

Kurt Lüscher (Konstanz)

Dimiter Philipov (Wien)

Tomáš Sobotka (Wien)

Heike Trappe (Rostock) 